\title{
KADAR ASAM LAKTAT, AMONIA DAN pH SILASE LIMBAH SINGKONG DENGAN PEMBERIAN MOLASES BERBEDA
}

\author{
M. RIDWAN, D. SAEFULHADJAR, DAN I. HERNAMAN \\ Fakultas Peternakan Universitas Padjadjaran \\ Jl. Raya Bandung Sumedang Km 21 Jatinangor Sumedang 45363 \\ e-mails: iman.hernaman@unpad.ac.id
}

\begin{abstract}
ABSTRAK
Penelitian bertujuan untuk melakukan pengawetan limbah perkebunan singkong dengan menggunakan aditif molases. Penelitian dilaksanakan secara eksperimental dengan menggunakan rancangan acak lengkap yang terdiri dari 4 perlakuan dan 5 ulangan. Data yang dihasilkan dianalisis sidik ragam pada taraf $\alpha=0,5 \%$ dan dilanjutkan dengan uji Duncan. Perlakuan berupa tingkat penggunaan molases pada level o\% (Po), 2\% (P1), 4\% (P2), dan $6 \%\left(\mathrm{P}_{3}\right)$. Hasil menunjukkan konsentrasi asam laktat meningkat signifikan $(\mathrm{P}<0,05)$, sedangkan konsentrasi ammonia menurun seiring dengan meningkatnya penggunaan molases. Hubungan antara asam laktat dengan $\mathrm{pH}$ menunjukkan korelasi negatif dengan persamaan regresi adalah y $=-0,3634 \mathrm{X}+6,0886$ dan nilai korelasi (r) sebesar 0,65 , sedangkan hubungan antara $\mathrm{pH}$ dengan kadar ammonia menghasilkan persamaan regresi $\mathrm{y}=1,9835 \mathrm{X}-$ o,2064 dengan nilai korelasi r yaitu o,64. Hasil penelitian disimpulkan bahwa molases dapat meningkatkan kadar asam laktat, namun menurunkan nilai $\mathrm{pH}$ dan ammonia serta penggunaan sebanyak $2 \%$ memberikan proses ensilase yang optimal.
\end{abstract}

Kata kunci: limbah singkong, molases, ruminansia, silase

\section{CONCENTRATION OF LACTIC ACID, AMMONIA AND PH OF CASSAVA WASTE SILAGE PROVIDING DIFFERENT LEVEL OF MOLLASES}

\begin{abstract}
The research aims to preserve cassava plantation waste using molasses additives. The study was conducted experimentally using a completely randomized design consisting of 4 treatments and 5 replications. The resulting data were analyzed for variance at the level of $\alpha=0.5 \%$ and continued with the Duncan test. The treatment was in the form of the use of molasses at $0 \%(\mathrm{Po}), 2 \%\left(\mathrm{P}_{1}\right), 4 \%\left(\mathrm{P}_{2}\right)$, and $6 \%\left(\mathrm{P}_{3}\right)$. The results showed that the lactic acid content increased significantly $(\mathrm{P}<0.05)$ with $\mathrm{P} 4$ producing the highest value, which is $6.90 \mathrm{mM}$. The $\mathrm{pH}$ value at the Po treatment was higher $(\mathrm{P}<0.05)$, but ammonia concentration decreases compared to the treatment using molasses. The relationship between lactic acid and $\mathrm{pH}$ showed a negative correlation with the regression equation was $\mathrm{y}=-0.3634 \mathrm{X}+6.0886$ and the correlation value $(\mathrm{r})$ of 0.65 , while the relationship between $\mathrm{pH}$ and ammonia resulted in a regression equation $\mathrm{y}=1.9835 \mathrm{X}-0.2064$ with a correlation value of $\mathrm{r}$ that is 0.64 . The results concluded that molasses can increase levels of lactic acid, but reduce the $\mathrm{pH}$ and ammonia and use as much as $2 \%$ to provide an optimal ensilage process.
\end{abstract}

Keywords: cassava waste, molasses, ruminants, silage

\section{PENDAHULUAN}

Perkebunan singkong menghasilkan umbi yang umumnya digunakan untuk industri tapioka dan sisanya untuk pakan ternak atau sebagai pangan manusia. Jumlah luas lahan di Indonesia Tahun 2018 yang digunakan sebagai perkebunan singkong sebesar 792.952 ha dan menghasilkan singkong sebanyak 19,34 juta ton (Kementerian Pertanian, 2019). Budidaya singkong tersebut menghasilkan limbah berupa daun, kulit dan batang singkong. Limbah ini belum termanfaatkan dengan baik, di kala musim panen tiba hanya sebagian yang dikonsumsi ternak, sisanya menjadi limbah di lokasi produksi. Hasil analisis Laboratorium Nutrisi Ternak Ruminansia dan Kimia Makanan Ternak, Fakultas Peternakan Universitas Padjadjaran menunjukkan bahwa kandungan nutrien limbah singkong adalah $87,79 \%$ bahan kering, $14,5 \%$ 
protein kasar, 5,17\% lemak kasar, 18,24\% serat kasar, $56,68 \%$ bahan ekstrak tanpa nitrogen (BETN) dan $5,41 \%$ abu.

Sisa dari limbah singkong yang belum dimanfaatkan dapat disimpan dan diawetkan untuk penyediaan pakan pada saat kekurangan pakan, terutama di musim kemarau. Kadar air dari limbah singkong saat panen berkisar 70\%-80\%. Kadar air yang tinggi menyebabkan limbah ini mudah membusuk sehingga pengawetan limbah singkong yang sesuai dengan kondisi tersebut yaitu dengan teknik pembuatan silase.

Silase merupakan teknologi pengawetan hijauan secara basah dengan kadar air tertentu yang menggunakan metode fermentasi anaerob (Dhalika et al. 2015). Selain dihasilkan asam laktat yang dapat menghambat perkembangan bakteri pembusuk, selama ensilase juga akan dihasilkan peroksida. Peroksida adalah zat kimia yang dapat membunuh bakteri pembusuk dan penghasil toksin (Surawiria, 2004). Silase juga terbukti dapat membunuh bakteri patogen, mereduksi pestisida dan residu obat-obatan pada substrat yang akan dibuat silase (Boda 1990; Bakshi dan Fontenot 1998).

Kandungan air merupakan hal yang harus diperhatikan, kadar air yang ideal untuk pembuatan silase sekitar 60\% (Hidayat 2014). Selain kadar air yang perlu diperhatikan adalah kandungan karbohidrat yang akan mempermudah proses fermentasi. Fermentasi dapat berlangsung dengan baik jika dalam substrat mengandung karbohidrat terlarut yang mencukupi (Ratnakomala et al., 2006). Karbohidrat tersebut akan digunakan sebagai sumber energi untuk mikroba dan difermentasi menjadi asam laktat dan asam lemak terbang, dimana senyawa ini dapat mengawetkan bahan pakan dalam pembuatan silase.

Untuk mempercepat proses fermentasi biasanya ditambahkan sumber karbohidrat, yaitu molases. Molases merupakan hasil samping dalam pembuatan gula tebu. Menurut Rukana et al. (2014) molases merupakan aditif karbohidrat yang sering digunakan dalam pembuatan silase. Berdasarkan hasil analisis di Laboratorium Nutrisi Ternak Ruminansia dan Kimia Makanan Ternak, molases mengandung karbohidrat yang diperlukan untuk menunjang pertumbuhan Lactobacillus sp., sehingga dapat memperlancar proses fermentasi. Molases mengandung 69,05\% bahan kering, 6,79\% protein kasar, o,84\% lemak kasar, o,66\% serat kasar, 85,88\% BETN dan 5,83\% abu. Kandungan BETNnya yang tinggi mencerminkan tinginya karbohidrat yang terlarut dalam molases.

Silase dikatakan baik bila pada proses kandungan zat-zat makanan dari bahan yang diensilase dapat dipertahankan semaksimal mungkin. Kehilangan zat makanan tersebut melalui respirasi dan degradasi protein (Jasin dan Sugiyono, 2014). Degradasi protein oleh bakteri Clostridia menyebabkan kadar ammonia menjadi meningkat dan menurunkan kualitas silase. Silase yang baik memiliki kadar ammonia tidak lebih dari 10\% dari N-Total.

Penelitian dilakukan untuk mengawetkan limbah perkebunan singkong dengan penambahan aditif molases.

\section{MATERI DAN METODE}

\section{Prosedur Pembuatan Silase Limbah Perkebunan Singkong}

Limbah perkebunan singkong berupa daun, kulit dan batang diperoleh dari Petani di Desa Cigendel Kecamatan Pamulihan, Kabupaten Sumedang dengan jenis singkong Mentega, sedangkan molases sebagai bahan aditif dibeli dari Koperasi Serba Usaha (KSU) Tandangsari, Tanjungsari Sumedang. Limbah perkebunan singkong dicacah dengan chooper, lalu dilayukan semalam, kemudian sesuai dengan takaran dicampur secara merata dengan molases $\mathrm{O} \%$ (Po), $2 \%$ (P1), 4\% (P2), dan 6\% (P3), sehingga mencapai 1000 g pada masing-masing perlakuan dengan lima kali ulangan. Kemudian dimasukan ke dalam plastik dan udara yang berada di dalam kantong yang telah berisi sampel disedot dengan menggunakan vacuum pump dan diikat dengan karet, lalu dimasukan ke dalam toples kedap udara. Silase tersebut disimpan di tempat yang aman untuk jangka waktu 1 bulan.

\section{Prosedur Pengukuran Asam Laktat}

Asam laktat diukur dengan menggunakan metode Cappucino dan Natalie (1991). Prinsip pengukuran kadar asam laktat adalah menghitung volume $\mathrm{NaOH}$ yang dipakai pada saat mentitrasi bahan dengan keterangan bahwa $1 \mathrm{ml} \mathrm{N} \mathrm{NaOH}$ yang dipakai untuk mentitrasi bahan sama dengan 9,008 gram asam laktat. Silase diaduk merata, kemudian diambil sampel sebanyak $10 \mathrm{~g}$ dimasukkan ke dalam Erlenmeyer lalu ditambahkan $10 \mathrm{ml}$ aquades. Sampel dipanaskan di atas hot plate sampai $\mathrm{CO}_{2}$ menghilang. Sampel didinginkan dan ditambahkan 5 tetes phenolpthalien ke dalam larutan sampel. Sampel dititrasi dengan menggunakan o, $1 \mathrm{~N} \mathrm{NaOH}$ sampai sampel berwarna merah muda (pink).

\section{Prosedur Pengukuran Ammonia}

Pengukuran ammonia dilakukan dengan metode microdifusi cawan Conway (Conway 1957). Silase yang telah diaduk diambil sebanyak $10 \mathrm{~g}$ dan dimasukkan ke dalam erlenmeyer dan dilarutkan dengan aquades sebanyak $40 \mathrm{ml}$. Sampel diaduk dengan menggunakan magnetik stirer. Kemudian dimasukkan ke dalam 
tabung dan disentrifuse selama 15 menit. Satu mL supernatan hasil preparasi silase ditempatkan pada salah satu sekat. Sebelumnya cawan Conway diberi vaselin pada permukaan bibirnya dan pada sisi yang lain ditempatkan $1 \mathrm{ml} \mathrm{Na}_{2} \mathrm{CO}_{3}$ jenuh, sedangkan bagian tengah cawan ditempatkan $1 \mathrm{ml}$ asam boraks berindikator. Cawan ditutup rapat dan digoyang-goyang agar supernatan dan $\mathrm{Na}_{2} \mathrm{CO}_{3}$ jenuh bercampur. Cawan dibiarkan selama 24 jam pada suhu kamar, setelah itu cawan dibuka. Asam boraks berindikator dalam cawan dititrasi dengan $\mathrm{H}_{2} \mathrm{SO}_{4}$ 0,0057 $\mathrm{N}$ sampai warnanya kembali merah muda.

\section{Prosedur Pengukuran Derajat Keasaman (pH)}

Sampel sebanyak 50 g dimasukkan ke dalam labu erlenmeyer. Kemudian ditambahkan $100 \mathrm{ml}$ aquades, lalu digiling menggunakan blender selama 1 menit. Campuran tersebut dimasukan ke dalam beaker glass dan diukur dengan $\mathrm{pH}$ meter yang telah distandarisasi dengan larutan buffer pada $\mathrm{pH} 7$ selama 10 menit, kemudian distandarisasi kembali dengan $\mathrm{pH} 4$ selama 10 menit.

\section{Analsis Statistik}

Penelitian menggunakan rancangan acak lengkap, dimana dilakukan secara eksperimental. Data yang terkoleksi diuji dengan analisis ragam pada taraf 0,5\% yang dilanjutkan dengan uji Duncan dan untuk mengetahui hubungan antara asam laktat dengan $\mathrm{pH}$ dan $\mathrm{pH}$ dengan ammonia dilakukan analisis regresi dan korelasi (Steel dan Torie 1995).

\section{HASIL DAN PEMBAHASAN}

Rataan hasil penelitian disajikan pada Tabel 1 . Berdasarkan hasil analsis sidik ragam menunjukkan bahwa penambahan molases berpengaruh nyata $(\mathrm{P}<0,05)$ terhadap kadar asam laktat, $\mathrm{pH}$ dan amonia silase limbah singkong. Kadar asam laktat meningkat secara nyata $(\mathrm{P}<0,05)$ seiring dengan meningkatnya penggunaan molases. Kadar asam laktat terendah pada perlakuan Po dan tertinggi diperoleh pada perlakuan $\mathrm{P}_{3}$ yaitu $5,58 \%$ dan $6,90 \%$. Sebaliknya kadar $\mathrm{pH}$ cenderung menurun dengan penambahan molases sebagai bahan aditif, meskipun perlakuan Po, P1, dan P2 tidak berbeda nyata. Rata-rata $\mathrm{pH}$ silase pada kisaran 3,46 ( $\left.\mathrm{P}_{3}\right)$ sampai dengan 4,09 (Po). Silase yang baik mempunyai $\mathrm{pH}$ 3,54,2. Berdasarkan hal tersebut nilai rata-rata $\mathrm{pH}$ yang dihasilkan masih dalam kisaran (Jamaru et al. 2014).

Sementara itu kadar amonia memiliki pola yang sama dengan $\mathrm{pH}$ yang menunjukkan terjadi penuruan seiring dengan penambahan molases. Kisaran nilai amonia hasil penelitian antara $6,5 \mathrm{mM}\left(\mathrm{P}_{3}\right)$ sampai dengan 8,53 mM (Po). Bila dikonversikan dalam bentuk persen, maka amonia yang dihasilkan berkisar antara 11,20-15\%. Menurut Departemen Pertanian (1980) silase kriteria baik memiliki amonia 10-15\%. Berdasarkan hal tersebut, maka nilai rata-rata amonia hasil penelitian masih diantara kriteria yang ditetapkan oleh Departemen Pertanian.

Tabel 1. Pengaruh perlakuan terhadap kosentrasi asam laktat, derajat keasaman $(\mathrm{pH})$ dan amonia

\begin{tabular}{lcccc}
\hline \multicolumn{1}{c}{ Peubah } & $\mathrm{P} 0$ & $\mathrm{P} 1$ & $\mathrm{P} 2$ & $\mathrm{P} 3$ \\
\hline Asam laktat $(\%)$ & $5,58 \pm 0,19^{\mathrm{a}}$ & $6,04 \pm 0,09^{\mathrm{b}}$ & $6,67 \pm 0,085^{\mathrm{c}}$ & $6,90 \pm 0,86^{\mathrm{d}}$ \\
Derajat keasaman $(\mathrm{pH})$ & $4,09 \pm 0,32^{\mathrm{b}}$ & $3,83 \pm 0,11^{\mathrm{b}}$ & $3,82 \pm 0,25^{\mathrm{b}}$ & $3,46 \pm 0,89^{\mathrm{a}}$ \\
Amonia/ $\mathrm{N}-\mathrm{NH}_{3}(\mathrm{mM})$ & $8,53 \pm 0,56 \mathrm{c}$ & $7,34 \pm 0,66 \mathrm{~b}$ & $6,95 \pm 0,52 \mathrm{ab}$ & $6,50 \pm 0,56 \mathrm{a}$ \\
\hline Keterangan: & & \\
Superskrip yang berbeda ke arah baris menunjukkan berbeda nyata $(\mathrm{P}<0,05)$ \\
P0 = 0\% molases, P1 = 2\% molases, P2 = 4\% molases, P3 = 6\% molases
\end{tabular}

Terjadinya peningkatan kadar asam laktat disebabkan karena penambahan molases, dimana bahan aditif ini mengandung karbohidrat terlarut yang tinggi. Karbohidrat yang terlarut dimanfaatkan oleh bakteri asam laktat untuk memproduksi asam laktat. Semakin tinggi molases yang ditambahkan maka semakin banyak substrat yang dimanfaatkan untuk memproduksi asam laktat.

Pada perlakuan P1 memiliki kadar asam laktat yang rendah di bawah kandungan asam laktat silase yang dikategorikan baik yaitu 5,35-10,65\% (Jasin, 2014). Hal ini diakibatkan kandungan karbohidrat terlarut yang terdapat limbah singkong tidak mencukupi untuk produksi asam laktat dengan optimal. Limbah perkebunan singkong yang memiliki porsi daun dan batang lebih banyak mengandung karbohidrat tidak terlarut yang tinggi $(18,24 \%)$ dalam bentuk serat kasar.

Perlakuan P3 menghasilkan kadar asam laktat yang tertinggi diantara semua perlakuan. Penambahan molases secara nyata terbukti mampu meningkatkan kadar asam laktat melalui sumbangan karbohidrat yang diberikan. Karbohidrat terlarut melalui proses fermentasi yang dilakukan oleh mikroorganisme dirombak menjadi asam organik terutama asam laktat, dan sebagian kecil asam asetat dan asam butirat. Oleh karena itu, karbohidrat terlarut penting sekali dalam ensilase agar dapat menjamin produksi asam laktat untuk mencegah fermentasi sekunder oleh bakteri Clostridia (Telleng, 2017) yang bersifat merugikan. Asam laktat merupakan indikator yang paling penting yang menandakan proses fermentasi berjalan dengan baik. Asam laktat sangat berpengaruh dalam mempercepat penurunan $\mathrm{pH}$ silase, sehingga kerusakan nutrien akibat perombakan oleh bakteri yang tidak diinginkan dapat ditekan.

Jasin (2014) menyatakan bahwa molases sebagai sumberenergibagimikroorganismeuntukmenghasilkan asam laktat yang menyebabkan penurunan $\mathrm{pH}$. Tinggi 
rendahnya nilai $\mathrm{pH}$ silase sangat bergantung pada pembentukan asam- asam organik terutama asam laktat (Harahap 2014). Cepatnya pembentukan asam laktat akan disertai dengan meningkatnya kondisi asam. Hal ini akan menyebabkan turunnya $\mathrm{pH}$ silase. Asam laktat mempunyai pengaruh yang paling besar terhadap penurunan $\mathrm{pH}$ silase, meskipun asam organik lainnya seperti asam asetat juga ikut berperan dalam penurunan $\mathrm{pH}$. Hubungan antara asam laktat dan $\mathrm{pH}$ dapat dilihat pada Gambar 1.

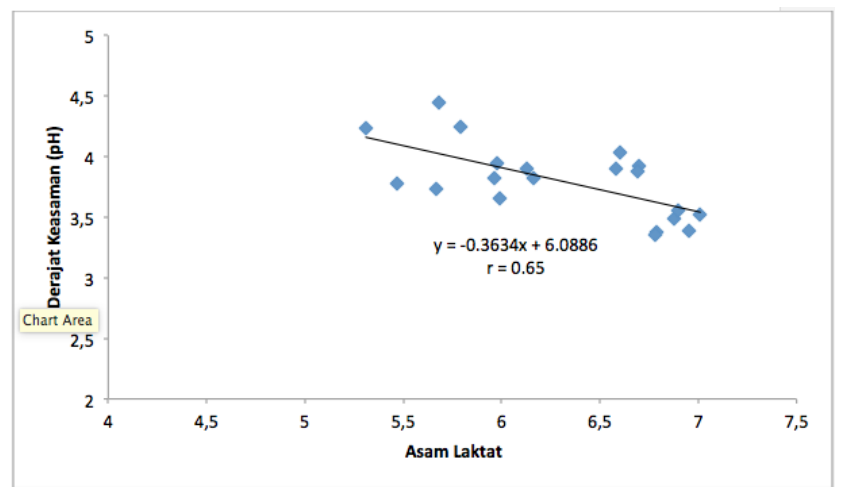

Gambar 1. Hubungan antara asam laktat dengan derajat keasaman $(\mathrm{pH})$

Gambar 1 menjelaskan bahwa seiring dengan peningkatan kadar asam laktat akan diiringi pula dengan menurunnya derajat keasaman $(\mathrm{pH})$ dengan persamaan regresi linear adalah $\mathrm{y}=-0,3634 \mathrm{X}+6,0886$ dan nilai korelasi (r) sebesar o,65. Nilai korelasi tersebut menggambarkan hubungan yang kuat antara kadar asam laktat dengan nilai pH (Sugiyono 2007).

Amonia adalah hasil perombakan protein oleh bakteri Clostridia (Bureenoket al. 2006). Selain itu, pada kondisi anaerob enzim protease juga berperan dalam proses proteolisis yang juga menghasilkan amonia. Oleh karena itu, diupayakan silase yang dihasilkan memiliki kadar amonia yang rendah. Rendahnya kadar amonia menunjukkan bahwa kandungan protein dari bahan yang diensilase dapat dijaga, dengan kata lain perombakan protein dapat ditekan. Penggunaan molases yang menjadi sumber karbohidrat terlarut sebagai sumber energi bagi bakteri asam laktat akan digunakan untuk mempercepat fermentasi yang menghasilkan asam laktat, sehingga berakibat menurunnya derajat keasaman (Gambar 1). Rendahnya derajat keasaman akan menekan pertumbuhan bakteri Clostridia yaitu bakteri yang tidak diinginkan yang merusak protein (Telleng, 2017). Hal ini sejalan dengan pendapat (Chalisty et al., 2017) bahwa karbohidrat terlarut (molases) akan mempermudah fermentasi, menambah keasaman dan mengurangi kerusakan protein.

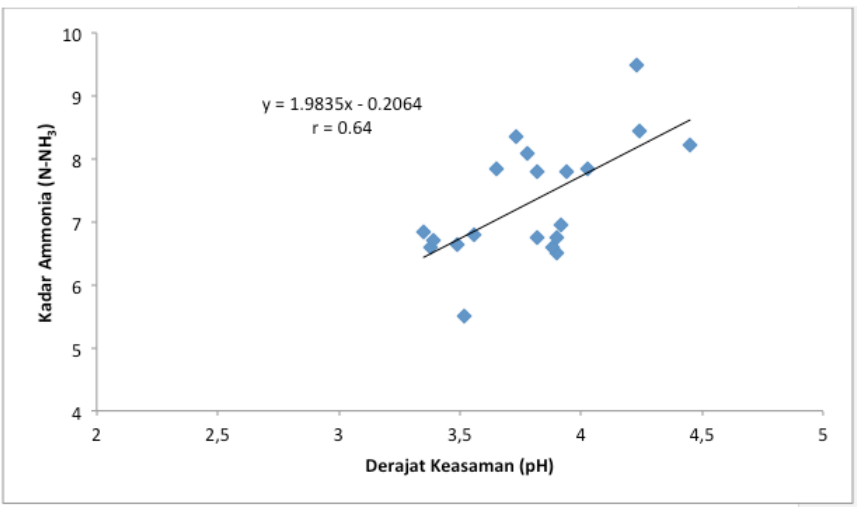

Gambar 2. Hubungan antara derajat keasaman $(\mathrm{pH})$ dengan kadar amonia (mM)

Berbeda dengan hubungan antara asam laktat dengan nilai $\mathrm{pH}$, maka hubungan antara $\mathrm{pH}$ dengan kadar amonia menunjukan korelasi yang positif membentuk persamaan regresi $\mathrm{y}=1,9835 \mathrm{X}-0,2064$ dengan nilai korelasi r yang kuat, yaitu 0,64 (Sugiyono, 2007). Hubungan tersebut menggambarkan bahwa semakin tinggi nilai $\mathrm{pH}$, maka kadar amonia juga meningkat.

Penambahan molases sebesar 6\% ( $\left.\mathrm{P}_{3}\right)$ adalah yang terbaik dilihat dari tingginya kadar asam laktat yang dihasilkan, selain itu $\mathrm{P}_{3}$ juga menghasilkan $\mathrm{pH}$ yang terendah dan amonia yang paling rendah pula. Penambahan molases sebesar 2\% dan 4\% (P1 dan P2) juga menurunkan kadar amonia namun tidak setinggi $\mathrm{P}_{3}$. Secara umum rata-rata data amonia yang dihasilkan oleh silase limbah singkong berada pada kisaran yang normal yaitu <15\% (Departemen Pertanian, 1980). Walaupun penambahan molases 6\% ( $\left.\mathrm{P}_{3}\right)$ terbaik, namun tidak berbeda hasilnya secara statistik dengan penggunaan molases $2 \%$ dan $4 \%$.

Penggunaan molases $2 \%$ memberikan pengaruh yang optimal dalam silase limbah singkong dilihat dari segi asam laktat, amonia dan $\mathrm{pH}$ serta mempengaruhi harga dari pembuatan silase limbah singkong karena molases merupakan bahan aditif yang harus dibeli oleh peternak.

\section{SIMPULAN}

Penggunaan molases dalam pembuatan silase limbah singkong dapat meningkatkan kadar asam laktat, menurunkan nilai $\mathrm{pH}$ dan amonia. Penggunaan molases sebanyak $2 \%$ memberikan proses ensilase yang optimal.

\section{UCAPAN TERIMAKSIH}

Penelitian ini dilaksanakan di Laboratorium Nutrisi Ternak Ruminansia dan Kimia Makanan Ternak, oleh karena itu penulis mengucapkan banyak terima kasih kepada kepala beserta anggota dan teknisi laboratorium. 


\section{DAFTAR PUSTAKA}

Bakshi, M. P.S. dan J. P. Fontenot. 1998. Processing and nutritive evaluation of broiler litter as livestock feed. Anim. Feed Sci. and Tech. 74:334-335.

Boda, K. 1990. Domestic refuse. In: Nonconventional Feedstuffs in the Nutrition of Farm Animals (Ed. K. Boda). Developments in Animal and Veterinary Sciences. 23. Elsevier. Amsterdam.

Bureenok, S., T. Namihira, S. Mizumachi, Y. Kawamoto dan T. Nakada. 2006. The effect of epiphytic lactic acid bacteria with or without different byproduct from defatted rice bran and green tea waste on napiergrass (Pennisetum purpureum Shumach) silage fermentation. J. Sci. Food Agric. 86:1073-1077.

Chalisty, V., R. Utomo, dan Z. Bachruddin, 2017. Pengaruh penambahan molases, Lactobacillus plantarum, Trichoderma viride dan campurannya terhadap kualitas total campuran hijauan. Buletin Peternakan, 411(4), 4311-4318.

Cappucino, J. G. dan S. Natalie. 1991. Microbiology: A Laboratory Manual. Rockland Community College State University of New York.

Conway, E. J. 1957. Microdiffusion of Analysis of Assosiation Official Analitycal Chemist: Goergia Press.

Departemen Pertanian. 1980. Silase sebagai Makanan Ternak. Departemen Pertanian. Balai Informasi Pertanian, Ciawi Bogor.

Dhalika, T., A. Budiman, dan Mansyur. 2015. Kualitas silase rumput benggala (Panicum maximum) pada berbagai taraf penambahan bahan aditif ekstrak cairan asam laktat produk fermentasi anaerob batang pisang. Jurnal Peternakan Indonesia 17 (1): 77-82

Harahap, A. E. 2014. Simulasi bakteri asam laktat yang diisolasi dari silase daun pelepah sawit pada saluran pencernaan ayam. Jurnal Peternakan 11 (2): 43-47

Hidayat, N. 2014. Karakteristik dan kualitas silase rumput raja menggunakan berbagai sumber dan tingkat penambahan karbohidrat fermentable. Agripet 14 (1): $42-49$
Jamarun, N. I. Ryanto, dan L. Sanda. 2014. Pengaruh penggunaan berbagai bahan sumber karbohidrat terhadap kualitas silase pucuk tebu. Jurnal Peternakan Indonesia 16 (2) : 114-118

Jasin, I. 2014. Pengaruh penambahan molases dan isolat bakteri asam laktat dari cairan rumen Sapi PO terhadap kualitas silase Rumput Gajah (Pennisetum purpureum). Agripet 14 : (1) 50-55

Jasin, I. dan Sugiyono. 2014. Pengaruh penambahan tepung gaplek dan isolat bakteri asam laktat dari cairan rumen sapi PO terhadap kualitas silase rumput gajah (Pennisetum purpureum). Jurnal Peternakan Indonesia 16(2):96-103.

Kementerian Pertanian Republik Indonesia. 2019. Statistik Pertanian. https://www.pertanian.go.id [Diakses 31 Maret 2020]

Ratnakomala, S., R. Ridwan, G. Kartina, dan Y. Widyastuti. 2006. Pengaruh inokulum Lactobacillus plantarum 1A-2 dan 1BL-2 terhadap kualitas silase rumput gajah (Pennisetum purpureum). Biodiversitas 7 (2) :131-134

Rukana, A. E. Harahap, dan D. Fitra. 2014. Karakteristik fisik silase jerami jagung (Zea mays) dengan lama fermentasi dan level molases yang berbeda. Jurnal Peternakan 11 (2) : $64-68$

Steel, R. G. D. and J. H. Torrie. 1993. Prinsip dan Prosedur Statistika. Edisi Kedua. PT Gramedia Pustaka, Jakarta (Diterjemahkan oleh B. Sumantri).

Sugiyono, 2007. Metode Penelitian pendidikan pendekatan kuantitatif, kualitatif, dan R\&D. Bandung: ALFABETA

Telleng, M.M. 2017. Penyediaan pakan berkualitas berbasis sorgum (Sorghum bicolor) dan Indigofera (Indigofera sollingeria) dengan pola tanam tumpangsari [disertasi]. Bogor (ID) : Institut Pertanian Bogor.

Surawiria, U. 2002. Pupuk Organik Kompos dari Sampah, Bioteknologi Agroindustri. Bandung: $\mathrm{Hu}-$ maniora Utama Press. 